\title{
Under the Hood of Tess: Conflicting Reproductive Strategies in Thomas Hardy's Tess of the D'Urbervilles
}

\section{Vladimir Tumanov}

\section{Neophilologus}

An International Journal of Modern and Mediaeval Language and Literature

\section{ISSN 0028-2677}

Volume 97

Number 1

Neophilologus (2013) 97:245-259

DOI 10.1007/s11061-012-9302-8

\section{Neophilologus}

An international journal

of modern and mediaeval language and literature

Vol. XCVII, No. 1, January 2013 


\title{
Under the Hood of Tess: Conflicting Reproductive Strategies in Thomas Hardy's Tess of the D'Urbervilles ${ }^{1}$
}

\author{
By Vladimir Tumanov \\ Western University
}

\begin{abstract}
Thomas Hardy's Tess of the D'Urbervilles is analyzed from an evocritical perspective in order to consider evolved human reproductive strategies through the psychology and behavior of the novel's three principal characters: Tess, Alec and Angel. It is argued that Hardy made the episode of Tess' and Alec's sexual contact, as well its interpretation by the characters, ambiguous, thereby suggesting the possibility of seduction rather than rape. In this context, two female mating patterns - inherited from our hominid ancestors - appear in Tess' behavior: a) the collection of high quality genes from a genetically fit male (Alec) who is not likely to stay with the female and provide for the offspring and b) mating with a provider male who is interested in long-term parental investment (Angel). Conversely, Angel and Alec represent two male mating strategies that evolved as possible courses of action in our species: the dad and the cad respectively. The unwillingness of Angel to forgive Tess her sexual past is considered in the context of another evolved feature of the human mind: paternal uncertainty (the fear of the male's genetic extinction through the possibility of raising another male's offspring). This is juxtaposed with studies of male jealousy in different cultures and periods. Tess' decision to tell Angel about her past is viewed in connection with the concept of modularity: an approach to human psychology based on the assumption that the mind is divided into specialized modules (responsible for different cognitive spheres) which can sometimes conflict.
\end{abstract}

Keywords Evolutionary psychology · Thomas Hardy ' Tess of the D'Urbervilles • Little Red Riding Hood ' Seduction versus rape ' Evocriticism ' British nineteenth-century fiction ' British twentieth-century fiction ' Human reproductive strategies ' Dad versus cad ' Paternal uncertainty ' Reproductive asymmetry · Male jealousy · Modular brain · Darwinism.

\footnotetext{
${ }^{1}$ Published article here: http://www.springerlink.com/content/v8g3395n1v7v52m7/
} 
The parallel between Thomas Hardy's Tess of the D'Urbervilles and Charles Perrault's "The Little Riding Hood" has been pointed out by a number of critics (e.g., Morgan, 1989: 118). A young woman goes to visit an old lady - the blind invalid Mrs. D'Urberville visited by Tess is like Little Red Riding Hood's poor old grandmother - and ends up mistreated in the deep dark woods by a "wolf." Like Perrault's hairy villain, the mustachioed Alec D'Urberville has his way with Tess in the fairy tale-like woods at Trantridge. Classic twentieth century readings of Perrault have suggested that the story of the wolf's "eating" the naive demoiselle is an allegory of rape (Brownmiller, 1976: 34344; cf. Orenstein, 2002: 147). This would make the fairy tale paradigmatic of a young female's precarious predicament in a world dominated by aggressive males. In line with this paradigm, Tess of the D'Urbervilles, has also been interpreted as a story of rape and its tragic consequences (Reed, 1988: 100). However, neither in Perrault's case nor in Hardy's is the question of rape an open-and-shut case. The moral appended to "Little Riding Hood" makes seduction an equally possible allegorical reading:

Je dis le loup, car tous les loups

Ne sont pas de la mesme sorte :

Il en est d'une humeur accorte,

Sans bruit, sans fiel et sans couroux,

Qui, privez, complaisans et doux,

Suivent les jeunes demoiselles

Jusque dans les maisons, jusque dans les ruelles.

Mais, hélas! qui ne sçait que ces loups doucereux

De tous les loups sont les plus dangereux! (Orenstein, 2002: 37) ${ }^{2}$

The tension between the rape and seduction readings of "Little Riding Hood" is evident from the terminology used in David Gurnham's discussion of the fairy tale's feminist interpretations. On the one hand, Gurnham talks of the wolf as a "smooth-talking seducer who preys on naïve little girls" (Gurnham, 2009: 96

2 “Children, especially attractive, well-bred young ladies, should never talk to strangers, for if they should do so, they may well provide dinner for a wolf. I say 'wolf,' but there are various kinds of wolves. There are also those who are charming, quiet, polite, unassuming, complacent, and sweet, who pursue young women at home and in the streets. And unfortunately, it is these gentle wolves who are the most dangerous ones of all" (Quoted in Gurnham, 2009: 97). 
- emphasis mine), but on the other hand, he refers to "Perrault's young heroine as an innocent victim of sexual violence" (Gurnham, 2009: 98).

Similar hermeneutic confusion surrounds various readings of the relationship between Tess and Alec in Hardy's novel. For example, in the latest cinematic interpretation of Tess of the D'Urbervilles (BBC: 2008), Tess is clearly raped by Alec, and yet, the film's DVD cover reads: "[A] thrilling story of seduction, love and betrayal" (emphasis mine). This is not surprising since Hardy's text does not give an account of what exactly happens on that fateful night between Tess and Alec (Hardy, 1965: 63), but there are hints that the rape reading is by no means the only possible one. Even before the event itself, there is a sense that Tess' attitude toward Alec may involve subconscious attraction. Thus, upon being asked to be his lover by Alec, Tess responds in a way that suggests she may be wavering despite herself: "I don't know-I wish-how can I say yes or no when-" (Hardy, 1965: 60). This is confirmed by the narrator who points out that Tess "[was] temporarily blinded by his ardent manners, had been stirred to confused surrender awhile" (Hardy, 1965: 69). Even long after the fact, Tess sees Alec as the possessor of "lip-shapes that had meant seductiveness" (Hardy, 1965: 253). Jennifer Gribble settles the rape-seduction controversy very convincingly:

Changes between 1892 and 1912 see Tess succumbing to Alec's persuasions in some measure, and by the 1912 version it is clear that Tess has remained at Trantridge as Alec's lover, despite her inner resistance to him: "If I had ever sincerely loved you, if I loved you still, I should not so loathe and hate myself for my weakness as I do now! ... My eyes were dazed by you for a little, and that was all" (p. 97). Here we seem to have a Tess who admits to sexual responsiveness, albeit against her better judgment. Mary Jacobus has argued that Tess's purity is a "literary construct ... stuck on in retrospect to meet objections the novel had encountered even before its publication in 1891" (Gribble, 1999: 9).

However, Ellen Rooney attempts to resolve the rape-seduction issue by arguing that "the passive object of seduction repeats the passive object of rape" 
(Rooney, 1991: 93) i.e., even seduced, Tess is as good as raped because Hardy fails to represent her as a "as a desiring or speaking subject" (Rooney, 1991: 96). However, James Heffernan objects that Tess is a desiring subject who lets herself be seduced, i.e., makes a decision with respect to her sexual behavior (Heffernan, 2005: 5). Heffernan points out that "because Tess never 'wholly' loved Alec, many critics seem to assume that she could not in any way have consented to intercourse with him. But [even a] 'pure' woman can be sexually roused by a man she does not love" (Heffernan, 2005: 9), which is evident from Tess' own assessment of the sexual encounter with Alec as "her weakness" (Hardy, 1965: 65).

Heffernan's insistence on returning sexual agency to Hardy's heroine (taken away from her not by Thomas Hardy, but by the critics with whom Heffernan argues) is significant for my purposes because the rest of this paper will argue that we may be dealing with a literary representation of profound psychological phenomena taking us back to the ancestral past of our hominid ancestors. This investigation is an attempt to look "under the hood" of the young female's reproductive position, as well as the positions of her potential mates, as reflected in fiction. What is at stake when a young woman faces the conflict between her own (conscious or unconscious) reproductive needs and those of the opposite sex? As the terminology used in the foregoing suggests, the approach that I would like to adopt is known as evocriticism, i.e., the attempt to see the bio-psychological and evolutionary forces underpinning human behavior modeled in works of fiction. The core of the satisfaction derived by generations of readers and listeners from perennial stories resides in this psychological modeling capacity of the story-telling art: "Virtually all novels and plays are about the same subject, even when disguised as history or adventure. If you want to understand human motives, read Proust or Trollope or Tom Wolfe, not Freud or Piaget or Skinner. [...] Great literary minds are, almost by definition, great mind-reading minds. Shakespeare was a far better psychologist than Freud, and Jane Austen a far better sociologist than 
Durkheim" (Riddley, 2003: 333). In other words, good authors can be trusted to represent the human mind well.

Evocriticism is an approach based on the assumption that certain evolved characteristics of the human psyche - behavioral tools that appeared through natural selection - are still there despite the veneer of modern civilization. When it comes to considering evolutionary change in our species, virtually no time has passed since the Stone Age, i.e., despite all the transformations brought about by human culture, our minds work the way they evolved to function on the African savannah many thousands of years ago. However much one may be tempted to view humans as being "in control," our behavior is still largely determined by feelings and emotions that helped us survive and reproduce in the Pleistocene. This implies that authors who represent the human condition authentically must willy-nilly show our "instincts" at work whether in a genteel parlor on the pages of Jane Austen's Pride and Prejudice or in the muck and passion of Joseph Conrad's Heart of Darkness. Brian Boyd sums up the new field in literary studies as follows: "A biocultural or evolutionary approach to fiction [...] let me call it 'evocriticism' [...] lets us link literature with the whole of life, with other human activities and capacities, and their relation to those of other animals. [...] It can connect literature $[\ldots]$ with ongoing research of various kinds that can refine and challenge our understanding of human nature and thought" (Boyd, 2009: 384-5).

In order to assess Tess of the D'Urbevilles from an evocritical perspective, let us begin at the beginning, i.e., hominid bipedalism. For biomechanical reasons, movement on two limbs instead of four involved the redesign of the pelvis which became narrower. The narrowing of the pelvis made the birth canal correspondingly tighter, and at the same time the human brain was evolving to a bigger size - hence a bigger cranium. Therefore, the human infant had to be born before its head became too big to fit through the birth canal. This meant that much of the brain development and cranial growth took place 
outside the womb: in the hostile world. Essentially, human infants are born premature - by primate standards. While a chimp infant is able to grasp its mother and do a great deal toward self-care very early on in its life-cycle, human infants are helpless for the first year and in need of much care until at least age four (cf. Gazzaniga, 2008: 46). Thus, the vulnerability of the human child and toddler makes a father's assistance a great advantage: the mother is tied down and cannot easily provide for her young or protect them on her own.

This is compounded by the fact that the human female produces a limited number of eggs in her lifetime and an even smaller number of young, not to mention that in the ancestral environment infant mortality was very high. The male, on the other hand, produces a virtually unlimited number of sperm and is not tied down by pregnancy or care for a "premature" infant over a considerable period of time. The result is potential conflict between the male and female reproductive strategies. While the male may benefit from trying to mate with as many females as possible - thereby aiming for quantity rather than quality in the hope that some of his progeny will survive even without his assistance - the female is constrained to be choosier and seek a mate who will help her raise the young. Mating with multiple partners can occasionally offer an advantage to the female, but this reproductive strategy is risky and far less common. Another reason for the male's tendency toward greater promiscuity is paternal uncertainty: while the female always knows that her genetic information is moving into the future when she produces a child, the male can never be absolutely certain that any given child is his. The latter danger means that a male always risks unwittingly investing precious resources in another male's progeny and allowing his own genes to go extinct. The likelihood of this extinction is reduced by increasing the number of matings and mates. As David Buss puts it,

in human evolutionary history, asymmetries with respect to reproduction have led men and women to pursue different reproductive strategies (Trivers, 1972). These strategies sometimes conflict with one another. [...] 
In humans and other mammals, male investment tends to be smaller than female investment. [...] In this context, female reproductive strategy is expected, relative to male strategy, to be more discriminating, involving withholding of mating until sufficient resources have been invested or promised by the male or until the "best" male is found. Indiscriminate copulation tends to be costly for females (Buss, 1989a: 735-36).

The male reproductive strategies stemming from this asymmetry are known as "dad" and "cad" (Kruger et al., 2003: 306). The dad strategy involves offering paternal care, i.e., favoring offspring quality rather than quantity. Although this increases the risk of male extinction (see paternal uncertainty above), the rewards include a greater likelihood of being able to see one's progeny survive to an age when the reproductive process will continue. The cad strategy is the "mate and run" approach outlined above, and it is often combined with the dad strategy as is evidenced, for example, by the tendency of men in Victorian society to live with their families and visit prostitutes on occasion. The female's response can also be dual:

Generally speaking, human females should have evolved to value and selectively 'trade-off' evidence of a mate's investment potential for evidence of his viability, contingent on various factors. For example, if a man is perceived as less investing than other available suitors, he must evince higher viability to be viewed as a commensurately attractive mate. If, however, he is seen as relatively more investing than other suitors, he need not be quite as high on viability to be perceived as attractive (Simpson and Lapaglia, 2007: 166)

The male favoring the cad strategy tends to be "high on viability" (to use Simpson's and Lapaglia's term), i.e., demonstrating easily identifiable genetic fitness. That boils down to raw physical attractiveness - high bodily symmetry, clear skin, broad shoulders, tall build, and prominent musculature - and often a propensity to engage in certain risk-taking behaviors. This is where the question of the young woman's attraction to the big bad wolf comes in, i.e., however threatening Perrault's villain may appear, a seduction reading of "Little Red Riding Hood" may carry the subtext of attraction. The wolf is a reckless predator - the image of masculine power and resolve - just the right 
type for the collection of survival genes by an ancestral female. No wonder Perrault warns the "jeunes demoiselles" in his moral: the danger resides in the wolf to be sure, but it can also lurk in Little Red Riding Hood's evolved hominid impulses.

In Tess of the D'Urbervilles, Alec is a cad male in that he pursues short-term matings rather than long-term paternal investment. His physical attractiveness and risk-taking behavior display the sort of immediately perceptible genetic fitness that may be found appealing. Although Alec's wild ride with Tess in his gig down a hill frightens and upsets the young woman (Hardy, 1965: 44), this reckless behavior is also associated with the "genetically fit" male type that may have promised good genes in the Pleistocene - a hardy hunter and fighter is likely to endow his progeny with such qualities. Tess' mother Joan Durbeyfield calls Alec "a mighty handsome man" (Hardy, 1965: 38) and a "handsome, horsey young buck" (Hardy, 1965: 42). The young farm maids of Trantridge who confront Tess on the fateful night of her encounter with Alec are former mistresses of the latter (Hardy, 1965: 57). And so, it is no wonder that Tess may feel subconsciously drawn toward Alec D'Urberville who is described as "a tall young man [...] [wearing a] well-groomed black moustache with curled points" (Hardy, 1965: 32). In a paradoxical twist, mating with a male that other females find attractive may produce "sexy sons," i.e., males that perpetuate this cycle by attracting yet more females etc. And this may outweigh the risks taken by a female who cannot count on paternal support from a cad mate (cf. Weatherhead and Robertson, 1979). Richard Dawkins elucidates Weatherhead's and Robertson's sexy son hypothesis as follows:

In a society where males compete with each other to be chosen as he-men by females, one of the best things a mother can do for her genes is to make a son who will turn out in his turn to be an attractive he-man. If she can ensure that her son is one of the fortunate few males who wins most of the copulations in the society when he grows up, she will have an enormous number of grandchildren. The result of this is that one of the most desirable 
qualities a male can have in the eyes of a female is, quite simply, sexual attractiveness itself (Dawkins, 1989: 158).

However, Tess' overt reaction to Alec is ostensibly negative. She disagrees with her mother regarding Alec's attractiveness (Hardy, 1965: 38) and tells Alec repeatedly that she does not love him: "I have said I will not take anything more from you, and I will not-I cannot! I should be your creature to go on doing that, and I won't!" (Hardy, 1965: 65). And yet, Tess' undoing may still be the result of seduction rather than rape because the involuntary feelings shaped in the human mind by natural selection can be very different from what rational considerations tell us. Robin Baker explains the tension that exists between conscious awareness and the deeper forces that can shape human behavior despite human intentions: "Whether we know it or not, whether we want to or not, and whether we care or not, we are all programmed to try to win our generation's game of reproduction - we are all programmed to pursue reproductive success. Our successful ancestors have saddled us inescapably with genetic instructions which tell us not only that we must compete, but also how to" (Baker, 2006: 4). In Tess' case, the "how to" may amount to giving in to Alec's advances despite everything she believes in.

Alec's assessment of Tess after their fateful reunion pinpoints the two main mating strategies open to the human female in the reproductive marketplace. Alec pictures Tess both as innocent and as a seductress: "You have been the means - the innocent means - of my backsliding [...] 'You temptress, Tess" (Hardy, 1965: 268; cf. Heffernan, 2005: 6). We have the "innocence" of pairbonding with an investing mate and the "temptation" involved in short-term mating with a genetically superior cad type. This sociobiological reading of Tess does not cancel out the author's intentions which included the robust criticism of the way Victorian social conventions could erect insurmountable barriers to the pursuit of personal fulfillment. However, herein lies the difference between proximate and ultimate causation of human action. In evolutionary psychology, proximate causes of behavior are those which can be readily identified by the 
individual or an observer, e.g., Tess' desire for happiness. Ultimate causes are the invisible and profound psychological processes guided by genetic interests which have nothing to do with happiness. To quote Steven Pinker: "People don't care about their genes; they care about happiness, love, power, respect, and other passions. The cost-benefit calculations are a metaphorical way of describing the selection of alternative genes over millennia, not a literal description of what takes place in a human brain in real time" (Pinker, 2002: 244).

However, although I have been discussing Tess' path in terms of the two main reproductive strategies within the human female's behavioral repertoire, Hardy's novel, as well as numerous psychological studies, indicates that these strategies are not of equal weighting. As has been argued above, the "sexy son" approach involving a cad father is riskier for the female than mating with a dad type. In fact, the risk posed by mating with a cad type is illustrated by the fate of Tess' baby. As if to demonstrate precisely what would have likely happened to an ancestral female without a supporting mate, Hardy does not allow his heroine's child to live past early infancy. Thus, the genetic gamble is attempted and lost, which suggests that reproductive success is more likely with a male who is not necessarily quite as high on the genetic viability scale as a cad mate. It is, therefore, not surprising that in Tess of the D'Urbervilles, the heroine's favored reproductive strategy is in line with more typical female behavior, i.e., a conservative approach involving greater discrimination in mate choice and preference for a dad partner.

Tess' encounter with Alec is summed in terms of right and wrong: "Thus the thing began. Had she perceived this meeting's import she might have asked why she was doomed to be seen and coveted that day by the wrong man, and not by some other man, the right and desired one in all respects" (Hardy, 1965: 35; cf. 62). The right man is of course Angel Clare whose dad characteristics appeal to Tess right away: "She had not known that men could 
be so disinterested, chivalrous, protective, in their love for women as he" (Hardy, 1965: 162). Like Perrault's wolf, the caddish Alec is a mating opportunist in that he takes advantage of the young woman's defenselessness. Angel, on the other hand, does the exact opposite as he reassures Tess: "You will not think I have presumed upon your defenselessness - been too quick and unreflecting, will you?" (Hardy, 1965: 128). His solicitous behavior toward Tess and the other women at Talbothays dairy farm is a display meant to suggest paternal investment potential - a cue that Tess picks up loud and clear:

Tess was woman enough to realize from their avowals to herself that Angel Clare had the honour of all the dairymaids in his keeping, and her perception of his care to avoid compromising the happiness of either in the least degree bred a tender respect in Tess for what she deemed, rightly or wrongly, the self-controlling sense of duty shown by him, a quality which she had never expected to find in one of the opposite sex, and in the absence of which more than one of the simple hearts who were his housemates might have gone weeping on her pilgrimage (Hardy, 1965: 119).

Angel's chivalric behavior is a form of fitness display - male fitness being defined in evolutionary terms not just as the visible physical attractiveness of an Alec D'Urbervile, but as any characteristics or behaviors that a female may find reproductively appealing. The episode where Angel carries Tess and the other three milkmaids across a river is accompanied by the following remark: "Angel Clare, to whom three-quarters of this performance was a commonplace act of kindness, now approached Izz" (Hardy, 1965: 121). The performance is of course meant for Tess - a demonstration of the "right" reproductive strategy in stark contrast with the "wrong" approach adopted by the wolfish Alec.

Arguably, the most pivotal moment in Tess of the D'Urbervilles is the conversation between Tess and Angel in their honeymoon abode right after the wedding. Tess has just received Angel's confession of a premarital sexual 
encounter whereupon she has related the sad story of her own illegitimate child fathered by Alec D'Urberville: "'Forgive me as you are forgiven! I forgive you, Angel.' 'Yes-yes, you do.' 'But you do not forgive me?' 'O Tess, forgiveness does not apply in this case!' " (Hardy, 1965: 191) Following this outrageously unfair exchange, Angel abandons Tess, which leads to her demise. The traditional reading of this scene is a sociopolitical and moral one: the unfairness of the misogynist double standard, Victorian hypocrisy with respect to class relations etc. And this is fair enough. In fact, this is precisely how Hardy wanted us to read his novel, and he helps us along by having the narrator elucidate Angel's psychology: "She broke into sobs, and turned her back to him. It would almost have won round any man but Angel Clare. Within the remote depths of his constitution, so gentle and affectionate as he was in general, there lay hidden a hard logical deposit, like a vein of metal in a soft loam, which turned the edge of everything that attempted to traverse it" (Hardy, 1965: 202).

However, we can attempt to look "under the hood" of Angel's behavior in order to discover the possible atavistic motivation behind his stubbornness and cruelty. Firstly, how accurate is it to refer to the "logical deposit" in Angel's mind as the mechanism behind the repudiation of Tess? Could Hardy be placing the cart before the horse in his understanding of what his own character is doing when the narrator observes: "Angel Clare was [...] in truth, more spiritual than animal [...] Though not cold-natured, he was rather bright than hot" (Hardy, 1965: 162)? An author can be very good at representing the human condition without fully understanding the psychology underlying the very behavior in question. ${ }^{3}$ In this connection, let us turn to Michael Gazzaniga's discussion of human emotions as primary motivators for various behaviors -

${ }^{3}$ Consider, for example, the discussion of William Golding's Lord of the Flies by the psychologist Judith Rich Harris who argues that the author fails to understand human group psychology in his depiction of what happens to the boys on their desert island (Harris, 2009: 115-121). 
the feelings that prompt us to act intuitively and without necessarily understanding the ultimate causes of our actions:

The proposal is that a stimulus induces an automatic process of approval (approach) or disapproval (avoid), which may lead to a full-on emotional state. The emotional state produces a moral intuition that may motivate an individual to action. Reasoning about the judgment or action comes afterward, as the brain seeks a rational explanation for an automatic reaction it has no clue about. This includes moral judgments, which are not often the result of actual moral reasoning (Gazzaniga, 2008: 128).

It is important to emphasize here that "reasoning about the judgment or action comes afterwards": Angel's cold logic is not what ultimately moves him to abandon Tess. That is merely the rationalization of something that he does intuitively, i.e., on the basis of a feeling hard-wired into the male psyche in the prehistoric past. To be sure, the sociocultural context of his day provides the mechanism of this rationalization but is not its prime mover.

I would argue that the evolved feelings associated with paternal uncertainty are at play here, which makes Angel very much "animal" (contra Hardy's narrator) in that he unknowingly follows an ancient instinct or genetically determined propensity to avoid any risk of raising another male's offspring: "A man has a lot to lose from his partner's infidelity. First, he may be tricked into devoting a lifetime of wealth and effort into raising another man's child. Secondly, he is at greater risk to sexually transmitted diseases, because his partner is at greater risk. [...] There are two ways in which a man may try to reduce the chances of his partner's infidelity. Crudely, these masquerade as possessiveness and jealousy" (Baker, 2006: 68-9; cf. Buss and Shackelford, 1996: 1152). However, as Daly et al. point out, the emotion of jealousy in the human male does not have to involve the awareness of paternal uncertainty (Daly et al., 1982: 13). This state of mind can be clothed in such post hoc modern rationalizations as social propriety, reputation etc. - ultimate causation hidden under many layers of proximate causation. This is reflected 
in Angel's reasoning when he accuses Tess of not being "initiated into the proportions of social things" when she fails to understand why he has rejected her (Hardy, 1965: 195). When he says to her "I do forgive you, but forgiveness is not all" (Hardy, 1965: 195), we witness the power of the grip that the anxiety associated with paternal uncertainty can have on the male psyche. The conscious part of his mind is willing to forgive because all the evidence indicates that Tess is an excellent mate, but the ancient, unconscious forces animating Angel's psychology drown out all logic and common sense. And this is why he remains unmoved by Tess' appeal to his reason: "'What have I done - what have I done! I have not told of anything that interferes with or belies my love for you. You don't think I planned it, do you? It is in your own mind what you are angry at, Angel; it is not in me. $O$, it is not in me, and I am not that deceitful woman you think me!"' (Hardy, 1965: 194). In his "own mind" indeed - very, very deep in his own mind.

Because, unlike the caddish Alec, Angel is a long-term reproductive investor, the "purity" of a prospective mate is essential to him. This is clear from Angel's first impression of Tess when he notices the maid at the dairy farm: "What a fresh and virginal daughter of Nature that milkmaid is!" (Hardy, 1965: 102) The emphasis placed on virginity may seem like a prejudice of the age, but in terms of our evolved emotions, we must remember that males who did not experience the anxiety associated with paternal uncertainty would have been genetically outcompeted by the jealous types. Angel Clare is, therefore, a typical Stone Age male, i.e., Tess' willingness to overlook Angel's sexual past but not the reverse can be understood if we use David's Buss' above-cited notion of "sexual asymmetry" - the idea that in the ancestral environment only the female could be absolutely certain that she was the parent of her offspring. This is why even in the late $20^{\text {th }}$ century - a time far more liberal than the Victorian age with respect to sexual mores - studies of mate selection criteria across many societies and continents have yielded similar results, namely that men emphasize paternity confidence in the form of 
preoccupation with female chastity while women stress the male's capacity to procure resources (Lancaster, 1994: 47; cf. Buss, 1989b: 3).

Similarly, the sexual asymmetry inherent in Angel's and Tess' respective reactions to the revelation of each other's "past" is echoed by Daly et al. who cite studies of American dating couples from the 1980s: "The men focused on possible sexual contact of their partner with the rival male while women were primarily concerned with their boyfriends' expending time, money, and attention upon the rival female" (Daly et al., 1982: 18). Along the same line of reasoning, according to the pioneering 1953 Kinsey Report, " $51 \%$ of their divorced American male sample considered extramarital intercourse by their spouses to be a major factor in their divorces, compared to just $27 \%$ of divorced women" (Daly et al., 1982: 13). Closer to Angel's horror at the thought that Tess is not a virgin, we can cite studies of Mediterranean (and other societies') social customs related to premarital chastity: "Failed virginity tests at wedlock may lead to annulment, permanent unmarriageability, and disgrace for the rejected bride's family. There is a large anthropological literature on the subject of 'honor and shame,' [...] A man can gain or lose honor by his deeds [...] A woman, however, can only lose honor for herself and her kin by unchaste or immodest behavior. For her, lost honor can never be regained" (Daly et al., 1982: 19; cf. Georgiu, 2005: 126). This would explain why in English and other languages there is no real masculine equivalent for the word "slut": the likes of "skirt chaser," "ladies' man" or "Don Juan" simply do not carry the same pejorative connotations. And just how old the masculine obsession with female virginity is can be glimpsed from a pericope in the biblical book of Numbers where the Israelites are ordered by God to raid the Midianites and "kill every woman who has known a man by sleeping with him. But all the young girls who have not known a man by sleeping with him, keep alive for yourselves" (Holy Bible: New Revised Standard Version, 1995: 31:1719). 
This explains why the "fallen woman" is a stereotype with such an old pedigree, taking us back at least to the biblical Mary Magdalene. The obsession with female purity informs the theology of the Fall, the cult of the Virgin Mary, the misogynist discourse by the Church Fathers, the witch hunts of the early Renaissance, the modern claustration and veiling of women in fundamentalist Muslim societies and the adultery laws of most societies which until recently were focused on female rather than male infidelity (cf. Tumanov, 2011). A key characteristic of "fallenness" is its irreversibility, and Tess is perfectly aware of how the male mind works as she considers Angel in the beginning of their relationship. Tess recognizes Angel's conservative reproductive strategy involving long-term investment and therefore begins by giving up on any possibility of having him as a mate. She considers the other three milk maids at Talbothays to be better genetic prospects because they are not "fallen": " [She] was in the eyes of propriety far less worthy of him than the homelier ones whom he ignored" (Hardy, 1965: 125; also see 119).

It is therefore no wonder that Angel's mother asks her son regarding Tess: "And that she is pure and virtuous goes without question? [...] Angel- is she a young woman whose history will bear investigation?" (Hardy, 1965: 219-221). Although she is a woman, Angel's mother adopts the masculine position - that of her son's evolved feelings regarding paternal uncertainty - because her genetic interests coincide with those of Angel. At the other end of the ring we find Tess' mother who is also well aware of how the male psyche works, which is why she urges in a letter that Tess conceal the tragic story of Alec's baby: "On no account do you say a word of your Bygone Trouble to him. I did not tell everything to your Father, he being so Proud on account of his Respectability, which, perhaps, your Intended is the same. Many a woman - some of the Highest in the Land - have had a Trouble in their time; and why should you Trumpet yours when others don't Trumpet theirs?" (Hardy, 1965: 161) The "clash" of the two mothers illustrates the frequent clash of the male and female reproductive strategies - the female occasionally seeking out the genes of the 
caddish but genetically attractive short-term mate and the investing dad male doing his best to thwart the female's potential for foul play. Note that Tess' mother refers to "many a woman" concealing their sexual past, i.e., what Tess does when she insists on being truthful is seen as the exception to the general trend - an exception that only serves to prove the "rule." To be sure, Tess" behavior is a key element in her characterization, underscoring her admirable moral stature and helping to create an unforgettable tragic heroine in English fiction. However, as is often the case with the confrontation between the ideal and the real, the behavioral options rejected by paragons of virtue tell us more about human nature than the virtuous path taken.

In recent years, psychologists have tended to view the human mind not as one big generalist entity but rather as a modular system, i.e., divided into areas (modules) that evolved to specialize in certain tasks (Gazzaniga, 2008: 129). One such mental area is the reciprocity module which became increasingly sophisticated and powerful because hominids became more and more social in the course of their development (cf. Gazzaniga, 2008: 132). The emotions associated with loyalty have to do with this module since they helped humans to cooperate and increase their chances of survival in a challenging environment. In the case of Tess' integrity with respect to Angel, we have an illustration of how powerful such feelings can be. However, as Hardy's novel illustrates, sometimes the modules can be at cross-purposes within the same human mind. The impulses of the reciprocity module do not necessarily coincide with the needs of the module that runs our reproductive interests and the associated emotions, such as love and attraction. On the one hand, the emotional glue holding together an existing bond within a mating pair is an excellent example of the reciprocity module at work. On the other hand, let us recall the two reproductive strategies available to the human female - shortterm mating with a genetically superior male vs. long-term pairing with an investing male. The former can create feelings of attraction to a cad male that undermine the emotions associated with loyalty to the investing male in the 
framework of the reciprocity module. The admission on the part of Tess' mother that she concealed her sexual past from Tess' father illustrates a practical way of resolving the clash of the two modules - a compromise that does take something away from the (moral) triumph of the reciprocity module but ends up making normal life and reproduction possible. Tess, on the other hand, neither lives nor reproduces with Angel.

Still, for all her superhuman integrity, the conflict within Tess' modular mind does illustrate her typically human nature. At one point, she considers not telling Angel about her past: "Was once lost always lost really true of chastity? she would ask herself. She might prove it false if she could veil bygones. The recuperative power which pervaded organic nature was surely not denied to maidenhood alone" (Hardy, 1965: 84). This is pressure from the reproductive module which must have helped so many ancestral females, as well as the "many a woman" referred to by Tess' mother (see above), to maximize their genetic potential. However, Tess' reciprocity module gains the upper hand as she decides to "confess" her past to Angel. His reaction also illustrates to what extent the male's reciprocity and reproductive modules can clash. There is no doubt that Angel's feelings of tender loyalty toward Tess are as genuine as hers are toward him: "How then should he look upon her as of less consequence than himself; as a pretty trifle to caress and grow weary of; and not deal in the greatest seriousness with the affection which he knew that he had awakened in her" (Hardy, 1965: 130). And yet, these emotions are overruled by the unconscious anxiety associated with paternal uncertainty stemming from the reproductive module of the male mind. The tragedy of Hardy's tale stems from the fact that the two protagonists end up with mismatched modules in their relationship: where reciprocity gains the upper hand, the reproductive emotions fail and the reverse. In the end, we can learn just as much about human nature from the failure of human relationships as we can from their success. However, failures make for better fiction. 


\section{Conclusion}

The reproductive strategies of three representative actors in human evolutionary history have been considered through the medium of Thomas Hardy's novel: the cad male, the dad male and the female who needs to chose between them. Michael Gazzaniga sums up the usefulness of literature as a field for exploring sociobiological issues: "Throughout world literature, there appears to be a limited number of scenarios, and they are all related to evolutionary concerns, such as protection from predators, parental investment, proper relationship with kin and non-kin, and mate selection, to name a few, and all fiction draws on these" (Gazzaniga, 2008: 224-225). None of this implies that literary characters always represent evolved human psychological adaptations - at least not necessarily in a neat one-to-one pattern. In deciding to come clean with Angel, Tess appears to go against the grain of what can be viewed as a typical female reproductive strategy although it has hopefully been demonstrated that Tess' mind is still equipped with the same modules as those found in other minds. In the end, it is just a question of relative modular weighting that determines the tragic course of events in Tess of the D'Urbervilles. While the way Tess undermines her own long-term mating prospects may be viewed as atypical in a certain sense, her short-term mating strategy with Alec - her "weakness" as she calls it - would represent a more biologically grounded behavior.

At the same time, although Angel's obsession with his potential mate's chastity may appear to be a classic case of paternal uncertainty, it by no means represents the entire range of male behavior. In fact, David Buss' research demonstrates that there is a lot of cultural variability with respect to female chastity valuation on the part of males, namely, less advanced (traditional) societies tend to place more male emphasis on female chastity in mate choice (Buss, 1989b: 11-12). This would imply that culture can attenuate, rechannel and transform our inherited psychological baggage as witnessed by the sexual 
revolution of the $1960 \mathrm{~s}$ and the greater tolerance for a variety of sexual behaviors in modern Western society. Needless to say, what was normal in Victorian society can appear in a very different light today. The pointlessness of the debate between determinism and social constructivism (cf. Pinker, 2002: $17,38,40)$ is reflected in the following conclusion by Daly et al:

No human attribute can fairly be called ineradicable. The problem is one of ontogenetic engineering - simple in principle however intractable in practice. In principle, it might be possible to socialize a child to whatever set of arbitrary values, but if one were to engineer an ontogeny that could eradicate attribute $X$, this achievement would have no bearing on the claim that attribute $X$ is an evolved aspect of human nature with such and such adaptive significance. In any case, male sexual jealousy is a robust phenomenon across existing ontogenetic and cultural diversity [...] Male jealousy cannot be understood as an arbitrary product of a specific social history. It is instead a predictable product of evolution (Daly et al., 1982: 24).

The dynamics of the nature-nurture interaction in human society and the human mind illustrates that we change and don't change at the same time. However emancipated and broad-minded we may have become in comparison to the mentality of a Victorian like Angel Clare, when it comes to jealousymotivated homicide for example, males are still much more likely to murder females than the reverse (Daly at al., 1982: 14-15). And so Little Red Riding Hood may be able to follow the advice in Perrault's moral and avoid the wolf, but the built-in emotions that draw her to the wolf are still there - under the hood.

As George Levine points out, Darwin's theory of evolution was a major influence in Thomas Hardy's worldview and artistic creation (Levine, 2009: 36). The bleakness of the human condition painted in Tess of the D'Urbervilles and other Wessex novels may on first glance be perceived as an extremely grim reading of Darwin: organisms caught in the inexorable flow of life that cares nothing about suffering, happiness or fulfillment. For all their faculty of free will, Tess and the two men in her life appear to be tossed about by the fury of 
passions that they can hardly control. However, despite this pessimism, Levine points to the "life-affirming implications of Hardy's work" (Levine, 2009: 38) a position that imbued the author's vision with hope in a seemingly hopeless world. The very existence of an individual as noble as Tess - whatever her tragic plight may be - is already a sign that fulfillment is possible. The ending of the novel is clearly a new beginning: Angel is given a second chance in the person of Tess' younger sister Liza-Lu whom he will presumably marry in order to fulfill Tess' last wish. The two of them walk away hand-in-hand from the place of Tess' execution, and at this point we have a sense that our evolved impulses take nothing away from the tremendous potential of the human mind. Without transcending their inherent reproductive psychology, Hardy's characters retain their basic dignity in a world so radically altered by Charles Darwin's thinking.

\section{Works Cited}

Baker, R. (2006). Sperm wars: infidelity, sexual conflict, and other bedroom battles. New York: Basic Books.

Boyd, B. (2009). The origin of stories: Evolution, cognition and fiction. Cambridge, Massachusetts: The Belknap Press of Harvard University Press.

Brownmiller, S. (1976). Against our will: Men, women and rape. New York: Bantam.

Buss, D. (1989a). Conflict between the sexes: Strategic interference and the evocation of anger and upset." Journal of Personality and Social Psychology, 56(5), 735-47.

Buss, D. (1989b). Sex differences in human mate preferences: Evolutionary hypotheses tested in 37 cultures. Behavioral and Brain Sciences, 12, 1-49.

Buss, David \& Shackelford, T. K. (1996). Betrayal in mateships, friendships, and coalitions. Personality and Social Psychology Bulletin, 22(11), 1151-1164.

Daly, M., Wilson, M. and Weghorst, S. J. (1982). Male sexual jealousy. Ethology and Sociobiology, 3 (1), 11-27

Dawkins, R. (1989). The selfish gene. New York: Oxford University Press. 
Gazzaniga, M. S. (2008). Human: The science behind what makes us unique. New York: HarperCollins.

Georgiu, S. N. (2005). Growing and learning in the Greek Cypriot family context. Advances in Psychology Research, 35, 121-141.

Gribble, J. (1999). Postmodern Tess: Recent readings of Tess of the d'Urbervilles." Sydney Studies, 25, 1-19.

Gurnham, D. (2009). Memory, imagination, justice: Intersections of law and literature. Burlington, VT: Ashgate.

Hardy, T. (1965). Tess of the D'Urbervilles. New York: Norton.

Harris R. J. (2009). The nurture assumption: Why children turn out the way they do. New York: Free Press.

Heffernan, James. (2005). Cruel persuasion: Seduction, temptation, and agency in Hardy's Tess." The Thomas Hardy Year Book, 35, 5-18.

Holy Bible. (1995). New Revised Standard Version. Grand Rapids: Zondervan.

Kruger, D. et al. (2003). Proper and dark heroes as dads and cads: Alternative mating strategies in British Romantic literature. Human Nature, 14(3), 305317.

Lancaster, J. B. (1994). Human sexuality, life histories, and evolutionary ecology. In A. S. Rossi (Ed.), Sexuality across the life course (pp. 39-62). Chicago: University of Chicago Press.

Levine, G. (2009). Hardy and Darwin: an enchanting Hardy? In K. Wilson (Ed.), A companion to Thomas Hardy (pp. 36-53). Malden, Mass.: WileyBlackwell.

Morgan, S. (1989). Sisters in time: Imagining gender in nineteenth-century British fiction. New York: Oxford University Press.

Orenstein, C. (2002). Little Red Riding Hood uncloaked: Sex, morality, and the evolution of a fairy tale. New York: Basic Books.

Pinker, S. (2002). The blank slate: The modern denial of human nature. New York: Penguin.

Reed T. (1988). Demon-lovers and their victims in British fiction. Lexington, KY: University Press of Kentucky. 
Riddley, Matt. (2003). The red queen: Sex and evolution of human nature. New York: HarperCollins.

Rooney, E. (1991). 'A little more than persuading': Tess and the subject of sexual violence." In L. A. Higgins and B. Silver (Eds.), Rape and representation (pp. 87-114). New York: Columbia University Press.

Simpson, J. A. \& Lapaglia, J. (2007). An evolutionary account of strategic pluralism in human mating: Changes in mate preferences across the ovulatory cycle. In J. P. Forgas et al. (Eds.), Evolution and the social mind: Evolutionary psychology and social cognition (pp. 161-177). New York: Psychology Press.

Tess of the D'Urbervilles. (2009). Dir. David Blair. BBC. BBC Warner. DVD.

Tumanov, V. (2011). Mary versus Eve: Paternal uncertainty and the Christian view of women. Neophilologus: International Journal of Modern and Mediaeval Language and Literature, 95(4), 507-521.

Weatherhead P.J. and Robertson, R.J. (1979). Offspring quality and the polygyny threshold: 'The sexy son hypothesis'. The American Naturalist, 113(2), 201-8. 